\title{
Non-transitional Cell Carcinoma of The Bladder: Single Center Experience
}

\author{
Mesanenin Transisyonel Hücreli Olmayan Kanserleri: Tek Merkez \\ Deneyimi
}

\author{
Gökmen Umut Erdem, Mutlu Doğan, Nebi Serkan Demirci, Yakup Bozkaya, Doğan Uncu, Nurullah Zengin \\ Ankara Numune Eğitim ve Araştırma Hastanesi, Medikal Onkoloji, Ankara, Turkey
}

Dergiye Ulaşma Tarihi: 19.08.2017 Dergiye Kabul Tarihi: 25.08.2017 Doi: 10.5505/aot.2017.83007

\begin{abstract}
ÖZET
GIRIŞ ve AMAÇ: Transisyonel hücreli olmayan mesane kanserleri nadir görüldüğü için literatürde daha az veri bulunmaktadır. Bu amaçla hastalar klinikopatolojik özellikleri, tedavi modaliteleri ve bunların prognoza etkileri açısından retrospektif olarak değerlendirilmiştir.

YÖNTEM ve GEREÇLER: Ekim 2004-Eylül 2014 tarihleri arasında kliniğimizde püre transisyonel hücreli olmayan mesane kanseri tanısı teyit edilen 30 hasta retrospektif olarak değerlendirildi. Transisyonel kanser içeren miks tümörler çalışma dışı bırakıldı.

BULGULAR: Çalışmamızda mesane kanserli hastaların \%7.6'sında transisyonel hücreli olmayan karsinom olup bunların \%3.9'u skuamöz hücreli karsinom (SHK), \%2'si adenokarsinom, \%1'i küçük hücreli karsinom (KHK) olup, \%0.7'si diğer transisyonel hücreli olmayan kanser tipleri idi. Çalışmaya dahil edilen 30 hastanın tanı anında ortanca yaşı 60 yıl (aralık; 22-82), erkek/kadın oranı 4: 1 (24 erkek, 6 kadın) ve tanı anında en sık semptom makroskopik hematüri (\%73.3) idi. 7 (\%23.3) hastada evre 2, 10 (\%33.3) hastada evre 3, 13 (\%43.3) hastada ise evre 4 hastalık saptandı. Ortanca takip süresi 10 ay olup hastaların \%80.0'ninde nüks/progresyon, \%76.7'sinde ölüm gerçekleşti. Hastaların ortanca sağkalımı 10.0 ay olup, histopatolojik alt tipler açısından anlamlı farklılık yok idi $(\mathrm{P}=0.30)$. Lenf nodu tutulumu ve uzak metastazı olan hastalar çalışma dışı bırakıldığında erken evre mesane kanserli 17 hastanın ortanca sağkalımı 13.1 ay olup, tedavi modaliteleri açısından değerlendirildiğinde $\mathrm{TUR} \pm \mathrm{KT} \pm \mathrm{RT}$ uygulananlarda 10.0 ay iken, cerrahi $\pm \mathrm{KT} \pm \mathrm{RT}$ uygulananlar ortanca sağkalıma ulaşmamıştı $(\mathrm{P}=0.07)$. Tanı anında ECOG performans durumunun $0-1$ olması $(\mathrm{P}=0.04), 60$ yaş ve altında olmak $(\mathrm{P}=0.04)$, evre 2 ya da 3 hastalığa sahip olmak $(\mathrm{P}=0.02)$, uzak metastazın olmaması $(\mathrm{P}=0.04)$ ortanca sağ kalımı olumlu etkileyen faktörler idi.

TARTIŞMA ve SONUÇ: Transisyonel hücreli olmayan mesane kanserli hastalarda histopatolojik alt tiplere göre gruplar arasında genel sağkalım farkı saptanmadı. Tanı anında ECOG performans durumunun 0-1 olması, 60 yaş ve altında olmak, evre 2 ya da 3 hastalığa sahip olmak, uzak metastazın olmaması ortanca sağkalımı olumlu etkileyen faktörler idi. Evre 4 hastalık dışındaki hastalarda cerrahi \pm kemoterapi ve/veya radyoterapinin sağkalımı anlamlı olarak artırdığı gözlendi.
\end{abstract}

Anahtar Kelimeler: Mesane kanseri, transisyonel hücre dışı, skuamöz hücreli karsinom, adenokarsinom

\section{ABSTRACT}

INTRODUCTION: Because non-transitional bladder cancers are rare, there is a few data in the literature. For this purpose, patients were evaluated retrospectively in terms of clinicopathologic characteristics, treatment modalities, and their prognostic effects.

METHODS: Thirty patients with pure non-urothelial bladder cancer, who were followed between October 2004 and September 2015, were evaluated retrospectively.

RESULTS: Out of 390 consecutive patients with bladder cancers, 30 had pure non-urothelial carcinoma (7.6\%): \%3.9 SqCC, \%2.0 AC, \%1.0 SmCC, \%0.7 another non-urothelial carcinoma. The median age of the patients was 60 years (range, 22-82 years) and the male/female ratio was 4: 1 (24 males and 6 females). The most common symptom was macroscopic hematuria (73.3\%). Seven patients (23.3\%) had stage II disease, ten patients (33.3\%) had stage III disease and thirteen patietns (43.3\%) had stage IV disease. The median follow-up period was 10.0 months, during which $80.0 \%$ experienced recurrence/progression, and $76.7 \%$ died. The median overall survival (OS) was 10.0 months and there was no significant difference in terms of histopathological subtypes $(\mathrm{P}=0.30)$. The median OS of seventeen patients with stage 2-3 was 13.1 months. The median survival for stage I-III patients treated with surgery $\pm \mathrm{CT} \pm \mathrm{RT}$ (median OS yet not reached) was longer than for those treated with TUR $\pm \mathrm{CT} \pm$ 
RT (10 months) $(\mathrm{P}=0.07)$. Univariate analysis revealed that younger age $(\mathrm{P}=0.04)$, stage $2-3$ disease $(\mathrm{P}=0.02)$, ECOG performance status $<2(\mathrm{P}=0.04)$, and the absence of metastasis $(\mathrm{P}=0.04)$ were factors indicating a good prognosis.

DISCUSSION AND CONCLUSION: In patients with non-urothelial cancer, there was no overall survival difference between groups in terms of histopathological subtypes. At the time of diagnosis, younger age, stage 23 disease, ECOG performance status $<2$, and the absence of metastasis were factors indicating a good prognosis. Surgery $\pm \mathrm{CT} \pm \mathrm{RT}$ resulted in significantly better OS, except for in patients with stage 4 disease.

Keywords: Bladder cancer, non-transitional, squamous cell carcinoma, adenocarcinoma

\section{Giriş}

Transisyonel ve non-transisyonel olarak kategorize edilen mesane kanserleri hem erkeklerde hem de kadınlarda en sık görülen genitoüriner malignensi olup U.S.A'de en sik görülen 5. Malignitedir(1). Mesane kanserlerinin \%5-7’sinden(2) daha azını oluşturan transisyonel olmayan karsinomaların çoğu (\%90) epitelyal orjinli [(skuamöz hücreli karsinom (SHK), adenokarsinom, küçük hücreli karsinom (KHK))] iken geriye kalanı nonepitelyal orjinlidir (sarkoma, karsinosarkoma, paraganglioma, melanom, lenfoma)(3).

Mesane tümörlerinin \%3-5'ini SHK, \%0.5-2'sini adenokarsinom, \%0.3-0.7'sini KHK oluştururken sarkomatoid tümörler, paraganglioma, melanom ve lenfoma ise $\% 0.1$ 'den daha azını oluşturur(2).

Transisyonel hücreli olmayan mesane kanserlerinin çoğu tanı esnasında ileri evrede olup kemoterapiye cevabı kötüdür ve agresif cerrahi yaklaşımlar gerektirir. Bu çalışmamızda kliniğimizde tanı ve tedavileri yapılan püre transisyonel hücreli olmayan mesane kanserli 30 hastanın klinikopatolojik özellikleri, tedavi modaliteleri ve cevap oranları ve sağkalım sonuçlarını inceledik.

\section{Gereç ve Yöntem}

Ekim 2004- Eylül 2014 tarihleri arasında merkezimizdehistopatolojik olarakpüre transisyonel hücreli olmayanmesane kanseri tanısı almış olan 30 hasta (24 erkek ve 6kadın) retrospektif olarak değerlendirildi. Transisyonel karsinom içeren miks tümörler çalışma diş1 bırakıldı.Hastaların demografik özellikleri, sistoskopik bulguları, transüretral rezeksiyon sırasında elde edilen patoloji, operasyon durumu, evre, tedavi, takipler sırasında görülen nüks, progresyon ve öülm açısından değerlendirildiler.Sağkalıma etki eden prognostik faktörler araştırıldı.

Evreleme Amerika birleşik kanser komitesine ait 7. bask1 evreleme sistemine göre yapıldı(4).Hastaların son durumları son kontrol tarihlerine göre ve hastane ölüm kayıt bildirim sistemi incelenerek belirlendi. Hastalar tedavinin tamamlanmasından sonra ilk 2 yıl için 3 ayda bir, sonraki 3 yıl için 6 ayda bir, daha sonra ise 12 ayda bir izleme alındı.

\section{Bulgular}

Adress for correspondence: Kocaeli Sağllk Bilimleri Üniversitesi Derince Eğitim ve Araştrma Hastanesi, Mediakl Onkoloji Kocaeli - Türkiye e-mail: gokmenumut@hotmail.com 
Hastaların karakteristik özellikleri Tablo 1'de özetlendi. Çalışmamızda mesane kanserli hastaların 7.6\%'sında transisyonel hücreli olmayan mesane kanserisaptandi. Bunlarında\%3.9'u SHK, $\quad \% 2$ 'si Adenokarsinom, \%1'i KHK olup \%0.7'si diğer tipler idi.

Histopatolojik

ve immünohistokimyasal bulgularla 15 olgu (\%50) SHK, 8 olgu (\%26.7) Adenokarsinom, 4 olgu (\%13.3) KHK, 2 olgu (\%6.6) sarkom, 1 olgu (\%3.3) ise lenfoma olarak değerlendirildi. SHK’lihastaların hiçbirisi şistozomiazis ile ilişkili değildi.

Çalışmaya dahil edilen 30 hastanın tanı anında ortanca yaş1 60 yıl (aralık; 22-82) ve erkek/kadın oranı 4:1 (24 erkek, 6 kadın) idi. 30 hastanın 22'sinde (\%73.3) başlangıç semptomu olarak en sik makroskopikhematüri mevcut idi.ECOG performans durumuna göre hastalar değerlendirildiğinde 21 hasta (\%70) ECOG 0-1, 9 hasta (\%30) ECOG 2-3 performansa sahip idi.Predispozan etken olarak sırayla 23 hastada (\%76.7) sigara içimi, 2 hastada kronik taş irritasyonu (\%6.7), 1 hastada (\%3.3) kalic1 ürinerkateterizasyon mevcut idi. Tümörün en sık yerleşim yeri mesane tabanı idi. Sıklık sırasıyla tümör yerleşim yerleri; taban, multipl yerleşim, posterior duvar, yan duvarlar, kubbe, ve anterior duvar idi.

Tümör diferansiasyonuna bakıldığında 7 hastada (\%23.3) iyi diferansiye, 10 hastada (\%33.3) orta derede diferansiye, 13 hastada (\%43.3) kötü diferansiye tümör mevcuttu. Hastalar TNM evrelemesine göre evrelendiğinde; 8 (\%26.6) hastada T2, 11
(\%36.7) hastada T3, 11 (\%36.7) hastada T4 tümör saptandı. 11 (\%36.7) hastada lenf nodu tutulumu olup, 6 hastada (\%20) uzak organ metastazı mevcut idi. 7 (\%23.3) hastada evre 2, 10 (\%33.3) hastada evre 3, 13 (\%43.3) hastada ise evre 4 hastalık olarak değerlendirildi.

Hastalar cerrahi açıdan değerlendirildiğinde 16'sına (\%53.3) transüretral rezeksiyon (TUR), 11'ine (\%36.7) radikal sistektomi, 3’üne (\%10) parsiyelsistektomi yapıldı.Hastaların 16'sına (\%53.3)TUR \pm Kemoterapi(KT) \pm Radyotarapi(R $\mathrm{T})$, 14'üne cerrahi $\pm \mathrm{KT} \pm \mathrm{RT} \quad$ uyguland. Hastaların \%30’u (n=9) tanı anında RT alırken, \%3.3’ü ( $\mathrm{n}=1$ ) nüks-progresyon döneminde $\mathrm{RT}$ ald1.

Hastaların $\quad \% 50^{\prime} \quad \operatorname{sine}(\mathrm{n}=15) \quad \mathrm{KT}$ uygulanmış olup bunların 8'i (\%53.3)KT'yiadjuvan olarak alırken 7'si (\%46.7) palyatif olarak aldı. En sık tercih edilen KT rejimi platinli kombinasyon KT rejimleri idi[(Gemcitabin+Platin (11 hasta), Platin+Etoposid (2 hasta)]. KT yanit oranlar1; 2 hastada parsiyel yanıt (2/15; \%13.3), 4 hastada stabil hastalık $(4 / 15 ; \% 26.7)$ ve 9 hastada progresif hastalık $(9 / 15 ; \% 60)$ mevcut idi.

Ortanca takip süresi tüm hastalar için 10 ay (aralık; 1.9-86.1) iken bu süre SHK için 7.7 ay, Adenokarsinom için 11.7 ay, KHK için 13.3 ay idi. Hastaların 24'ünde (\%80.0) nüks/progresyon saptandı ve nüks/progresyon gelişen hastaların 6'sına (\%20.0) palyatif KT uygulanabildi. İki hastada stabil hastalık, 4 hastada progresif hastalık saptandi.

Çalışma analizi sırasında hastaların çoğunda (\%76.7) ölüm mevcut idi.Hastaların ortancaprogresyonsuzsağkalımı (PFS)6.0 ay 
iken ortancahastalıksız sağkalımı (DFS) 13.2 ayidi. Ortanca PFS, SHK ve KHK için sırayla 6.0 ay /5.6 ay olup subgruplar arasinda PFS açısından fark yok idi $(\mathrm{P}=0.18)$. OrtancaDFS,SHK, Adenokarsinom ve diğer tipleriçin sırayla8.5 ay /13.2 ay /7.9 ay idi $(\mathrm{P}=0.47)$.

Ortanca genel sağkalım(OS)10.0 ay idi. Histopatolojik alttiplere göre ortanca OS Adenokarsinom, KHK, SHK ve diğer tipler için s1rasi ile 21.1 ay, 11.0 ay, 7.7 ay ve 12.7 ay idi $(\mathrm{P}=0.30)$.

Lenf nodu tutulumu ve uzak metastazı olan hastalar çalışma dışı bırakıldığında erken evre mesane kanserli 17hastanın ortanca genel sağkalımı13.1 ay olup, tedavi modaliteleri açısından değerlendirildiğinde $\mathrm{TUR} \pm \mathrm{KT} \pm \mathrm{RT}$ uygulananlarda 10.0 ay iken, cerrahi $\pm \mathrm{KT} \pm \mathrm{RT}$ uygulananlar ortancasağkalıma ulaşmamıştı ( $\mathrm{P}=0.07)$ (Şekil 1).

Tanı anında ECOG performans durumunun 0-1 olması $(\mathrm{P}=0.04), 60$ yaş ve altında olmak ( $\mathrm{P}=0.04)$, evre 2 yada 3 hastalığa sahip olmak $(\mathrm{P}=0.02)$, uzak metastazın olmaması $(\mathrm{P}=0.04)$ ortanca sağkalımı olumlu etkileyen faktörler idi. Hasta sayısının az olması nedeni ile çok değişkenli analiz yapılmadı.

Tablo1: Hastaların genel özellikleri

\begin{tabular}{|l|c|}
\hline Özellikler & Hastalar n=30 (\%) \\
\hline Yaş; ortanca (yıl) & $60(22-82)$ \\
\hline Cinsiyet & $24(80.0)$ \\
Erkek & $6(20.0)$ \\
Kadın & $21(70.0)$ \\
\hline ECOG performans durum & $(30.0)$ \\
$0-1$ & \\
$2-3$ & $23(76.7)$ \\
\hline Predispozan faktörler & $2(6.7)$ \\
Sigara & $1(3.3)$ \\
Ürolitiyazis & $4(13.3)$ \\
Kateter & $22(73.3)$ \\
Yok & $5(16.7)$ \\
\hline Semptom & $3(10.0)$ \\
\hline Makroskopikhematüri & \\
İrritatifsemptomlar & $4(13.3)$ \\
Diğer & $1(3.3)$ \\
\hline Tümör lokalizasyonu & $4(13.3)$ \\
Kubbe & $12(40.0)$ \\
Anterior & $4(13.3)$ \\
Posterior & $5(16.7)$ \\
\hline Taban & \\
Yan duvarlar & $15(50.0)$ \\
Multiple & $8(26.7)$ \\
\hline Histolojik tip & $4(13.3)$ \\
Skuamöz hücreli karsinom & $3(10.0)$ \\
Adenokarsinom & $7(23.3)$ \\
Küçük hücreli karsinom & $10(33.3)$ \\
Diğer* & $13(43.3)$ \\
\hline Tümorgrade & $8(26.6)$ \\
1 & $11(36.7)$ \\
2 & $11(36.7)$ \\
3 T evresi & \\
II & \\
III & \\
IV & \\
\hline & \\
\hline
\end{tabular}




\begin{tabular}{|c|c|}
\hline \begin{tabular}{|l} 
N evresi \\
Negative \\
Pozitif
\end{tabular} & $\begin{array}{l}19 \text { (63.3) } \\
11(36.7)\end{array}$ \\
\hline $\begin{array}{l}\text { Uzak Metastaz } \\
\text { Yok } \\
\text { Var } \\
\end{array}$ & $\begin{array}{c}24(80.0) \\
6(20.0) \\
\end{array}$ \\
\hline $\begin{array}{l}\text { Tümor evresi } \\
\text { Evre } 2 \\
\text { Evre } 3 \\
\text { Evre } 4\end{array}$ & $\begin{array}{l}7(23.3) \\
10(33.3) \\
13(43.3)\end{array}$ \\
\hline $\begin{array}{l}\text { Cerrahi } \\
\text { TUR } \\
\text { Radikal sistektomi } \\
\text { Parsiyelsistektomi } \\
\end{array}$ & $\begin{array}{l}16(53.3) \\
11(36.7) \\
3(10.0)\end{array}$ \\
\hline $\begin{array}{l}\text { Tedavi } \\
\text { Transüretralrezeksiyon } \pm \mathrm{KT} \pm \mathrm{RT} \\
\text { Cerrahi } \pm \mathrm{KT} \pm \mathrm{RT}\end{array}$ & $\begin{array}{l}16(53.3) \\
14(46.7)\end{array}$ \\
\hline
\end{tabular}

*Sarkom(2), Lenfoma (1), KT: Kemoterapi, RT: Radyoterapi

Tablo 2: Genel sağkalım için Univariate analiz

\begin{tabular}{|c|c|c|c|}
\hline Özellikler & Hasta sayıs1 (\%) & OS için univariatenaliz (Ay) & P değeri \\
\hline $\begin{array}{l}\text { Yaş (y1l) } \\
\leq 60 \\
>60\end{array}$ & $\begin{array}{l}17(56.7) \\
13(43.3)\end{array}$ & $\begin{array}{c}15.7 \\
8.9\end{array}$ & 0.04 \\
\hline $\begin{array}{l}\text { Cinsiyet } \\
\text { Erkek } \\
\text { Kadın }\end{array}$ & $\begin{array}{l}24(80.0) \\
6(20.0)\end{array}$ & $\begin{array}{c}8.9 \\
21.1\end{array}$ & 0.10 \\
\hline $\begin{array}{l}\text { ECOG performans durum } \\
0-1 \\
2-3\end{array}$ & $\begin{array}{c}21(70.0) \\
9 \quad(30.0)\end{array}$ & $\begin{array}{c}13.0 \\
8.0\end{array}$ & 0.04 \\
\hline $\begin{array}{l}\text { Histolojik tip } \\
\text { Skuamöz hücreli karsinom } \\
\text { Adenokarsinom } \\
\text { Küçük hücreli karsinom } \\
\text { Diğger* }\end{array}$ & $\begin{array}{l}15(50.0) \\
8(26.7) \\
4(13.3) \\
3(10.0) \\
\end{array}$ & $\begin{array}{c}7.7 \\
21.1 \\
11.0 \\
12.7 \\
\end{array}$ & 0.30 \\
\hline $\begin{array}{l}\text { Tümorgrade } \\
1-2 \\
3 \\
\end{array}$ & $\begin{array}{l}17(56.6) \\
13(43.3) \\
\end{array}$ & $\begin{array}{c}8.9 \\
11.0 \\
\end{array}$ & 0.92 \\
\hline $\begin{array}{l}\text { T evresi } \\
\text { II-III } \\
\text { IV }\end{array}$ & $\begin{array}{l}19(63.3) \\
11(36.7)\end{array}$ & $\begin{array}{c}12.7 \\
6.6\end{array}$ & 0.03 \\
\hline $\begin{array}{l}\text { N evresi } \\
\text { Negative } \\
\text { Pozitif } \\
\end{array}$ & $\begin{array}{l}19(63.3) \\
11(36.7) \\
\end{array}$ & $\begin{array}{c}12.7 \\
8.0 \\
\end{array}$ & 0.06 \\
\hline $\begin{array}{l}\text { Uzak Metastaz } \\
\text { Yok } \\
\text { Var } \\
\end{array}$ & $\begin{array}{c}24(80.0) \\
6(20.0) \\
\end{array}$ & $\begin{array}{c}12.7 \\
5.8 \\
\end{array}$ & 0.04 \\
\hline $\begin{array}{l}\text { Tümor evresi } \\
\text { Evre 2-3 } \\
\text { Evre } 4 \\
\end{array}$ & $\begin{array}{l}17(56.6) \\
13(43.3) \\
\end{array}$ & $\begin{array}{c}13.1 \\
8.0 \\
\end{array}$ & 0.02 \\
\hline $\begin{array}{l}\text { Tedavi (Evre 2-3 hastalıkta) } \\
\text { Transüretralrezeksiyon } \pm K T \pm R T \\
\text { Cerrahi } \pm K T \pm R T\end{array}$ & $\begin{array}{c}10(58.9) \\
7(41.1) \\
\end{array}$ & $\begin{array}{c}10.0 \\
-\end{array}$ & 0.07 \\
\hline
\end{tabular}

*Sarkom(2), Lenfoma (1), KT: Kemoterapi, RT: Radyoterapi 


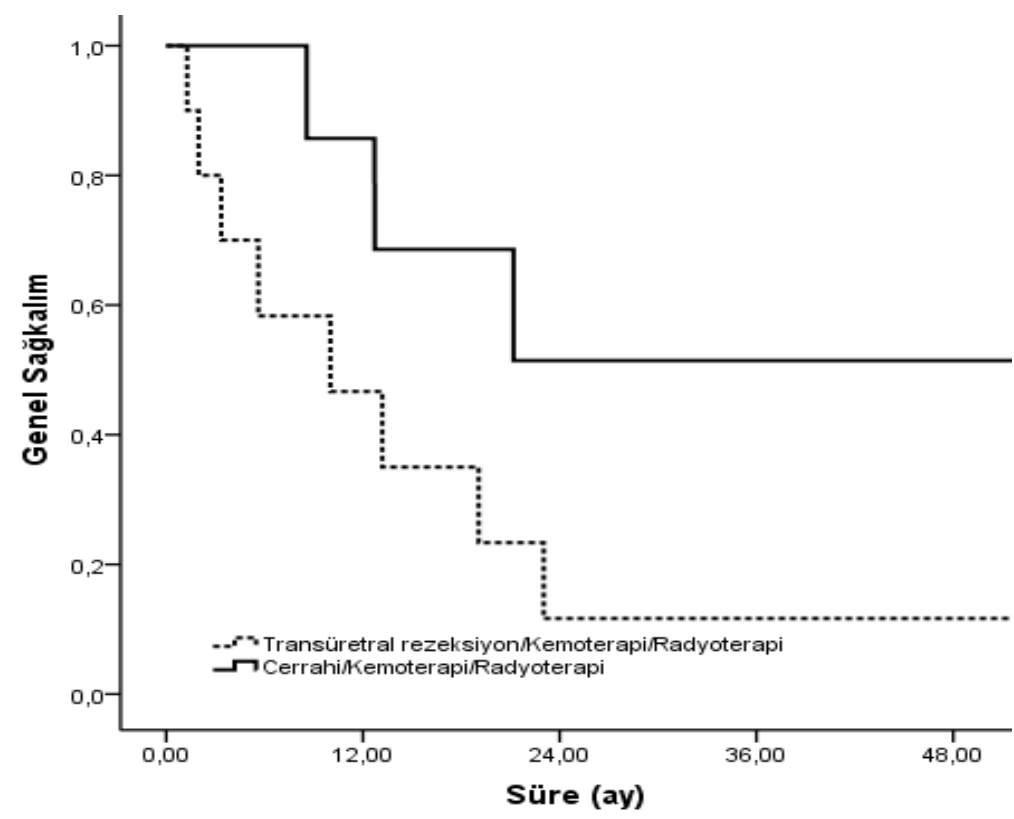

\section{Tartışma}

Transisyonel hücreli olmayan mesane kanserlerinininsidansı düşük oluphistolojik tiplerine göre değişik sıklıkta görülür.Yapılan çoğu çalışmalarda transisyonelkanserlerden farklı bir biyolojik davranış sergilediği, tanı anında ileri evre tümörler olup yapılan tedavilere rağmen sağkalım oranları düşük saptanmıştır(2).

Amerikada mesane kanserlerinin \%5’indendaha azını oluşturan transisyonel hücreli olmayan kanserlerin çoğunluğunu SHK(\%3-5), Adenokarsinom (\%0.5-2) ve KHK $(\%<0.5) \quad$ oluşturur. Geriye kalan histolojiler(sarkoma, karsinosarkoma, paraganglioma, melanom, lenfoma) hastaların \%0.1'inden daha azını oluşturur(2).Çalışmamızda transisyonel olmayan kanser insidansı\%7.6 olarak saptanmıştır. Literatürle uyumlu olarak bunlarında $\quad \% 3.9$ 'u $\quad$ SHK, $\% 2$ 'si Adenokarsinom, \%1'i KHK olup \%0.7'si diğer transisyonel olmayan kanser tipleri idi. Hiçbir hasta şistozomiazis enfeksiyonu ile ilişkili değildi.

Transisyonel hücreli olmayan mesane kanserleri erkek predominansı ile 6. Dekad sırasında ortaya çıkmaktadır(5).Çalışmamızda da hastaların ortanca yaşı 60 olup, erkek predominans1 mevcuttu. Hastaların en sik başvuru şikayeti literatür ile uyumlu olarak makroskopik hematüri (\%73.3) idi(6). Transisyonel hücreli olmayan kanser gelişiminde risk faktörü olan sigara içimi hastaların \%77'sinde mevcut idi(7).

Çoğu transisyonel hücreli olmayan mesane kanserlerindetanı anında kas invazyonu mevcuttur(6, 8-10).Çalışmamızda da hastaların tamamın da kas invazyonu saptanmıştır.Tanı anında ileri evreye (T3-4) sahip hastaların oranı SHK, Adenokarsinom ve KHK'lihastalar da sirayla \%60-84(5, 11-15), \%66-68(16, 17) ve \%51-80(5, 18) bulunmuștur. Çalışmamızda da literatür ile uyumlu olarak sirayla \%73.3, \%74.0 ve \%75.0 olarak bulunmuştur. 
Tanı anında genelde T3-4 evreye sahip SHK'lı hastalarda çoğu transisyonel hücrelikarsinomdan farklı olarakuzak metastaz oranı düşüktür (\%8-\%27.7)(6, 11).KHK'l1 hastalar ise transisyonelkarsinomdan daha kötü sağkalım ve daha fazla metastaz potansiyeline (\%37-45) sahiptir(15, 19, 20).Çalışmamızda da SHKve KHK' de uzak organ metastazı \%33.3 ve $\% 25.0$ oranı ile literatüre paralel idi.

Transisyonel hücreli olmayan kanserlerde yapılan çalışmalarda sağkalıma etkili olan faktörler evre(11, 12, 16, 21, 22), lenf nodu tutulumu(11, 12, 21, 23), grade(11, 12, 21, 22) ve SHK dış1(5) histolojidir.Yapılan çalışmalarda(24)kadınlar erkeklere göre daha ileri evrede tanı almakta ve daha kötü sağkalıma sahip olduğu gösterilmesine rağmen bizim çalışmamızda bu fark gösterilmedi. Çalışmamızda tek değişkenli analiz ile değerlendirildiğinde sağkalımı kötüleştiren faktörler ECOG performans durumunun 2-3 olması $(\mathrm{P}=0.04), 60$ yaş üzerinde olmak $(\mathrm{P}=0.04)$, evre 4 hastalığa sahip olmak $(\mathrm{P}=0.02)$, uzak metastazın olması $(\mathrm{P}=0.04)$ idi.Transisyonel hücreli olmayan kanserlerin histolojik alt tipleri arasında literatürle uyumlu olarak sağkalım farkı saptanmadı(23, 25, 26).

Lenf nodu tutulumu ve uzak metastazı olan hastalar çalışma dışı bırakıldığında erken evre mesane kanserli 17 hastanın ortanca sağkalımı13.1 ay olup, tedavi modaliteleri açısından değerlendirildiğinde $\mathrm{TUR} \pm \mathrm{KT} \pm \mathrm{RT}$ uygulananlarda ortanca sağkalım 10.0 ay iken, cerrahi $\pm \mathrm{KT} \pm \mathrm{RT}$ uygulananlar da ortanca sağkalıma ulaşmamıştı $(\mathrm{P}=0.07)$. Bu sonuçlarda literatür ile uyumlu olarak erken evre mesane kanserli hastalarda cerrahinin gerekliliğini vurgulamaktadır(26, 27).

75 yaş ve üstü hastalarda sağkalım daha kötüdür. Bunun nedeni yaşlı hastalara daha konservatif tedavilerle yaklaşılmasından hatta bazen tedavi verilmemesinden kaynaklanabilir. Bizim çalışmamızda da 60 yaş üstü hastalar daha kötü genel sağkalıma sahip idi (P:0.04). Tedavinin ilk basamağını oluşturan cerrahi tedavininileri yaş grubu hastalarda da kabul edilebilir mortalite ve morbidite ile güvenle yapılabileceği gösterilmiştir(28-30).

Çalışmamızın limitasyonları retrospektif olması ve hasta sayımızın düşük olmasıdır.

\section{Sonuç}

Transisyonel hücreli olmayan mesane kanserli hastalar daha ileri evrede tanı alır ve transisyonelkarsinomlardan daha kötü sağkalıma sahiptir. Vaka serileri ve literatür incelendiğinde rekürrens ve sağkalım açısından cerrahi daha iyi bir seçenektir.Adjuvan ve neoadjuvan tedavilerin rolü belirsiz kalmaya devam etmektedir.

Özetle çalışmamızdaki verilerin 1şı̆̆ında kötü prognostik faktörleri olmayan yani ECOG performas durumu iyi, lenf nodu tutulumu olmayan hastalarda radikal sistektomi ile birlikte kemoterapi ve/veya radyoterapi uygulanmasının sağkalıma katkısı mevcuttur.

\section{Çıkar Çatışması: Yok}

\section{Kaynaklar}

1. SEER Cancer Statistics Factsheets: Bladder Cancer. National Cancer Institute. Available from: http://seer.cancer.gov/statfacts/html/urinb.html. 
2. Dahm P, Gschwend JE. Malignant nonurothelial neoplasms of the urinary bladder: a review. European urology. 2003;44(6):672-81.

3. Murphy WM, Beckwith JB, Farrow GM. Tumors of the kidney, bladder and related urinary structures. In Atlas of Tumor Pathology. Volume 3, Third series, Fascicle 11. Washington: Armed Forces Institute of Pathology, 1994: 193-288.

4. AJCC Cancer Staging Manual. 7th edition. 2010. p497-502.

5. Rogers CG, Palapattu GS, Shariat SF, Karakiewicz PI, Bastian PJ, Lotan Y, et al. Clinical outcomes following radical cystectomy for primary nontransitional cell carcinoma of the bladder compared to transitional cell carcinoma of the bladder. The Journal of urology. 2006;175(6):2048-53; discussion 53.

6. Manunta A, Vincendeau S, Kiriakou G, Lobel B, Guille F. Non-transitional cell bladder carcinomas. BJU international. 2005;95(4):497-502.

7. Fortuny J, Kogevinas M, Chang-Claude J, Gonzalez CA, Hours M, Jockel KH, et al. Tobacco, occupation and non-transitional-cell carcinoma of the bladder: an international case-control study. International journal of cancer Journal international du cancer. 1999;80(1):44-6.

8. Abol-Enein $\mathrm{H}$, Kava BR, Carmack AJ. Nonurothelial cancer of the bladder. Urology. 2007;69(1 Suppl):93-104.

9. Gilligan T, Dreicer R. The atypical urothelial cancer patient: management of bladder cancers of nontransitional cell histology and cancers of the ureters and renal pelvis. Seminars in oncology. 2007;34(2):145-53.

10. Siefker-Radtke AO, Dinney CP, Abrahams NA, Moran C, Shen Y, Pisters LL, et al. Evidence supporting preoperative chemotherapy for small cell carcinoma of the bladder: a retrospective review of the M. D. Anderson cancer experience. The Journal of urology. 2004;172(2):481-4.

11. El-Sebaie M, Zaghloul MS, Howard G, Mokhtar A. Squamous cell carcinoma of the bilharzial and nonbilharzial urinary bladder: a review of etiological features, natural history, and management. International journal of clinical oncology. 2005;10(1):20-5.

12. Lagwinski N, Thomas A, Stephenson AJ, Campbell S, Hoschar AP, El-Gabry E, et al. Squamous cell carcinoma of the bladder: a clinicopathologic analysis of 45 cases. The American journal of surgical pathology. 2007;31(12):1777-87.

13. Guo CC, Gomez E, Tamboli P, Bondaruk JE, Kamat A, Bassett R, et al. Squamous cell carcinoma of the urinary bladder: a clinicopathologic and immunohistochemical study of 16 cases. Human pathology. 2009;40(10):1448-52.

14. Abdollah F, Sun M, Jeldres C, Schmitges J, Thuret R, Djahangirian O, et al. Survival after radical cystectomy of non-bilharzial squamous cell carcinoma vs urothelial carcinoma: a competing-risks analysis. BJU international. 2012;109(4):564-9.

15. Ploeg M, Aben KK, Hulsbergen-van de Kaa CA, Schoenberg MP, Witjes JA, Kiemeney LA. Clinical epidemiology of nonurothelial bladder cancer: analysis of the Netherlands Cancer Registry. The Journal of urology. 2010;183(3):915-20.

16. Grignon DJ, Ro JY, Ayala AG, Johnson DE, Ordonez NG. Primary adenocarcinoma of the urinary bladder. A clinicopathologic analysis of 72 cases. Cancer. 1991;67(8):2165-72.

17. Zaghloul MS, Nouh A, Nazmy M, Ramzy S, Zaghloul AS, Sedira MA, et al. Long-term results of primary adenocarcinoma of the urinary bladder: a report on 192 patients. Urologic oncology. 2006;24(1):13-20.

18. Cheng L, Pan CX, Yang XJ, Lopez-Beltran A, MacLennan GT, Lin H, et al. Small cell carcinoma of the urinary bladder: a clinicopathologic analysis of 64 patients. Cancer. 2004;101(5):957-62.

19. Quek ML, Nichols PW, Yamzon J, Daneshmand S, Miranda G, Cai J, et al. Radical cystectomy for primary neuroendocrine tumors of the bladder: the university of southern california experience. The Journal of urology. 2005;174(1):93-6.

20. Mukesh M, Cook N, Hollingdale AE, Ainsworth NL, Russell SG. Small cell carcinoma of the urinary bladder: a 15-year retrospective review of treatment and survival in the Anglian Cancer Network. BJU international. 2009;103(6):747-52.

21. el-Mekresh MM, el-Baz MA, Abol-Enein H, Ghoneim MA. Primary adenocarcinoma of the urinary bladder: a report of 185 cases. British journal of urology. 1998;82(2):206-12.

22. Richie JP, Waisman J, Skinner DG, Dretler SP. Squamous carcinoma of the bladder: treatment by radical cystectomy. The Journal of urology. 1976;115(6):670-2.

23. Girgin C, Sezer A, Uc R, Ermete M, Ozkan U, Gurel G. Outcome of the treatment of invasive nontransitional cell carcinoma. International journal of urology : official journal of the Japanese Urological Association. 2003;10(10):525-9.

24. Ploeg M, Aben KK, Kiemeney LA. The present and future burden of urinary bladder cancer in the world. World journal of urology. 2009;27(3):289-93.

25. Nishiyama $\mathrm{H}$, Habuchi $\mathrm{T}$, Watanabe J, Teramukai S, Tada H, Ono Y, et al. Clinical outcome of a large-scale multi-institutional retrospective study for locally advanced bladder cancer: a survey including 1131 patients treated during 1990-2000 in Japan. European urology. 2004;45(2):176-81.

26. Arslan B, Bozkurt IH, Yonguc T, Vardar E, Degirmenci T, Kozacioglu Z, et al. Clinical features and outcomes of nontransitional cell carcinomas of the urinary bladder: Analysis of 125 cases. Urology annals. 2015;7(2):177-82.

27. Martin JW, Carballido EM, Ahmed A, Farhan B, Dutta R, Smith C, et al. Squamous cell carcinoma of the urinary bladder: Systematic review of clinical characteristics and therapeutic approaches. Arab journal of urology. 2016;14(3):183-91.

28. Chang SS, Alberts G, Cookson MS, Smith JA, Jr. Radical cystectomy is safe in elderly patients at high risk. The Journal of urology. 2001;166(3):938-41.

29. Figueroa AJ, Stein JP, Dickinson M, Skinner EC, Thangathurai D, Mikhail MS, et al. Radical cystectomy for elderly patients with bladder carcinoma: an updated experience with 404 patients. Cancer. 1998;83(1):141-7.

30. Peyromaure M, Guerin F, Debre B, Zerbib M. Surgical management of infiltrating bladder cancer in elderly patients. European urology. 2004;45(2):147-53; discussion 54. 